\title{
Bimbingan Konseling Spiritual Terhadap Pasien Rehabilitasi Napza
}

\author{
Muhammad Hafizh Ridho' \\ Universitas Islam Negeri (UIN) Kalijaga Yogyakarta
}

\begin{abstract}
This study aims to determine the spiritual behavior of patients rehabilitating drugs. This discussion is entitled "Spiritual Counseling Guidance to Rehabilitation Patients". This research is qualitative with a descriptive approach that is observation, an interview. The results showed that the implementation of the rehabilitation of the Patients of Drugs can also be in the form of personality by providing guidance and counseling on the spiritual aspect which includes the aspect of Prayer Fulfillment performed by the five subjects are conducted simultaneously namely the practice of worship, the belief of life (Universality) as well as the responsibility of their life (Linkage) they have fully undergone as rehabilitation patients. There are an attitude and mental change from a previously dependent patient to a person who can manage himself well and more appreciate the meaning of life.
\end{abstract}

Keywords: Counseling guidance; spiritual; patient rehabilitation

\begin{abstract}
Abstrak
Penelitian ini bertujuan untuk mengetahui perilaku spiritual pasien rehabilitasi Napza. Pembahasan ini berjudul "Bimbingan Konseling Spiritual Terhadap Pasien Rehabilitasi Napza". Penelitian ini bersifat kualitatif dengan pendekatan deskriptif yaitu melakukan observasi, dan wawancara. Hasil penelitian menunjukkan bahwa pelaksanaa rehabilitasi Pasien Napza juga dapat di bentuk kepribadiannya dengan memberikan bimbingan dan konseling pada aspek spiritualnya yang mencakup aspek Pengamalan ibadah (Prayer Fulfillment) yang dilakukan oleh kelima subjek dilakukan secara besamaan yaitu pengamalan ibadah, Keyakinan hidup (Universalitas) serta tanggung jawab terhadap kehidupannya (Keterkaitan) yang telah mereka jalani sepenuhnya sebagai pasien rehabilitasi Napza. Terdapat adanya perubahan sikap dan mental dari pasien yang sebelumnya ketergantungan manjadi pribadi yang dapat mengelola dirinya dengan baikdan lebih menghargai arti kehidupan.
\end{abstract}

Kata kunci: Bimbingan konseling; spiritual; pasien rehabilitasi.

\section{Pendahuluan}

Masalah penyalahgunaan Narkotika, Psikotropika dan Zat Adittif lainnya (NAPZA) merupakan masalah yang sangat kompleks, untuk itu diperlukannya upaya penanggulangan secara komprehensif dengan melibatkan kerja sama multisektor antara pihak berwajib serta

${ }^{1}$ Korespondensi untuk tulisan ditujukan kepada email m.hafizhridho33@gmail.com 
masyarakat secara aktif dan berkesinambungan. Di kedokteran sebagian besar golongan obatobatan ini masih bermanfaat bagi pengobatan, namun dapat juga disalahgunakan dengan tidak menurut indikasi medis yang berlaku atau tidak dengan standar pengobatan terlebih lagi bila disertai peredaran di jalur illegal, akan berakibat sangat merugikan bagi individu atau masyarakat luas khususnya generasi muda.

Maraknya pernyalahgunaan Napza tidak hanya di kota-kota besar, namun sudah merambah kota-kota kecil di seluruh wilayah Indonesia. Hubungan Napza dengan generasi muda dewasa ini sangat amat erat. Sangat banyak kasus kecanduan dan pengedaran Napza yang terlibat di dalamnya adalah generasi muda, khususnya para remaja sekolah dan luar sekolah (mereka yang tidak bersekolah). Usia remaja telah menjadi sasaran empuk terhadap penyalahgunaan Napza, karena masa remaja merupakan masa pencarian identitas diri, dimana saat masa remaja munculnya rasa keingintahuan yang lebih, serta ingin mencoba berbagai hal baru dan bahkan juga hal yang beresiko. Oleh karenanya tidak menutup kemungkinan semakin hari maka jumlah pengedar, dan pengguna Napza akan meningkat.

Penyalahgunaan Napza saat ini menjadi masalah yang semakin meluas dan telah menjadi keprihatinan berbagai pihak, banyak nilai kemanusiaan yang mulai luntur dari Napza. Apabila bahan atau zat ini masuk ke dalam tubuh maka akan mempengaruhi tubuh terutama susunan syaraf pusat atau otak sehingga jika disalahgunakan akan menyebabkan gangguan fisik, psikis/ jiwa dan terganggunya fungsi sosial seorang individu. Penanggulangan yang dilakukan terhadap Napza sudah dilakukan oleh berbagai pihak dengan banyak cara. Salah satu cara penanggulangannya adalah memberikan sistem pembinaan salah satunya dilakukan di Rumah Sakit Jiwa. Penanganan pasien dengan program rehabilitasi di Rumah Sakit Jiwa merupakan bentuk upaya untuk membantu pasien agar bisa kembali menjadi pribadi yang bisa diterima di kehidupan bermasyarakat, serta berbagai permasalahan dialami pasien rehabilitasi dalam menjalani kehidupannya.

Rumah Sakit Jiwa (RSJ) menjadi tempat rehabilitasi dan penyembuhan bagi individuindividu yang mengalami sakit secara psikis atau kejiwaan. Berdasarkan studi pendahuluan yang dilakukan melalui proses wawancara langsung kepada Pimpinan Rumah Sakit Jiwa Sambang Lihum. Data Pasien masuk rawat inap jiwa dan napza di Rumah Sakit Jiwa Sambang 
Lihum pada tahun 2015 menunjukan bahwa pasien jiwa rawat inap sebanyak 1480 orang dan pasien Napza sebanyak 207 orang, jadi pada tahun 2015 pasien masuk rawat inap sebanyak 1687 orang. Kemudian pada tahun 2016 menunjukan bahwa pasien jiwa rawat inap sebanyak 1671 orang dan pasien napza sebanyak 333 orang, jadi pada tahun 2016 pasien masuk rawat inap sebanyak 2004. Pada tahun 2017 sampai dengan bulan Oktober pasien jiwa rawat inap sebanyak 1405 orang dan pasien napza sebanyak 345 orang, jadi pada tahun 2017 jumlah pasien rawat inap sebanyak 1750 orang. Dari proses wawancara yang dilakukan data yang didapat tentunya terdapat peningkatan jumlah pasien pada tahun sebelumnya yaitu pada tahun 2015 sampai 2016, kemudian terdapat penurunan jumlah pasien pada tahun 2017.

Kebijakan dari rumah sakit khususnya bagian kerohanian adalah memberikan bimbingan spiritual kepada setiap pasien rawat inap. Kebijakan tersebut ternyata belum semuanya pasien mendapat bimbingan spiritual (do'a) dari petugas spiritual, sehingga pasien masih merasa kurang diperhatikan masalah psikologis kecemasan, sedangkan yang sering diperhatikan hanya keadaan fisik pasien Aktifitas spiritual ini mempunyai dampak yang positif bahwa aktifitas spiritual dapat meningkatkan kemampuan beradaptasi disaat seseorang sakit (Suratih, Suranah, \& Riyanto, 2014).

Tujuan pelayanan bimbingan rohani di rumah sakit yaitu untuk membantu pasien yang mengalami problem psikis, sosial dan religius yang sebagian besar juga dialami pasien disamping penyakit fisik yang diderita. Layanan bimbingan rohani yang berupa pemberian nasehat, dan motivasi sampai pada pemecahan pribadi pasien diharapkan dapat mengatasi problem-problem di luar jangkauan medis sehingga pada akhirnya pasien dapat mencapai kesehatan yang menyeluruh baik dari aspek fsik, psikis, sosial maupun religius serta diharapkan dapat menciptakan loyalitas pelanggan untuk komunitas beragama (Kementerian Kesehatan RI, 2007).

Dalam pembahasan mengenai bimbingan konseling yang berhubungan pada kepribadian spiritual seorang pasien rehabilitasi telah menjadi salah satu terobosan terhadap individu yang mengalami kegoncangan mental sehingga menyebabkan terjadinya gangguan terhadap kepribadian seorang individu. Sebab-sebab tersebut individu secara tidak langsung akan 
mengalami tekanan karena beban pikiran sehingga dapat menjadi stres. Dampak tekanan yang muncul keluar menimbulkan berbagai macam penyakit baik jasmani maupun rohani.

Kesadaran akan pentingnya penanganan Napza sebagai salah satu upaya membantu para dengan cara memberikan pasien bimbingan koseling spiritual sebagai alat untuk memahami kekhasan atau keunikan individu bahwa mereka bisa bangki dari kesalahan yang mereka lakukan. Hal ini menjadi sebuah paradigma bahwa bimbingan konseling spiritual di kembangkan agar memiliki fungsi pemulihan kesadaran, pengetahuan dan kemampuan secara efektif pada fenomena sosial pasien rehabilitasi Napza (Lee, 2014). Keadaan pasien bukan saja merasakan sakit secara fisik, tetapi psikisnya pun telah menjadi sakit, mindset-nya terganggu, bahkan spiritualnya juga terimbas sakit. Dengan keadaan pasien yang seperti itu, aspek-aspek yang harus diperhatikan untuk membantu penyembuhan pasien seperti itu bukan saja terfokus pada aspek fisik, tetapi juga perlu menyentuh aspek-aspek lain seperti dimensi psikis, sosial, maupun religiusnya (Komarudin, 2010).

Berangkat dari uraian tersebut, maka penulis tertarik meneliti tentang "Bimbingan Konseling Spiritual Terhadap Pasien Rehabilitasi Napza Di Rumah Sakit Sambang Lihum."

\section{Bimbingan Konseling dalam Konteks Spiritual}

Sesuai dengan perkembangan kajian keilmuan definisi bimbingan pun turut berkembang dengan tanpa meninggalkan makna esensinya sebagai proses kegiatan pemberian bantuan (helping relationship). Menurut Prayitno bimbingan adalah proses pemberian bantuan yang dilakuakan oleh seseorang ahli kepada seseorang atau beberapa orang individu, baik anakanak, remaja, maupun dewasa, agar orang yang dibimbing dapat mengembangkan dirinya sendiri dan mandiri, dengan memanfaatkan kekuatan individu dan sarana yang ada dapat dikembangkan berdasarkan norma-norma yang berlaku (Prayitno, 2004). Moh. Surya mendefinisikan bimbingan adalah suatu proses pemeberian bantuan yang terus menerus dan sistematis dari pembimbing kepada yang dibimbing agar tercapai kemandirian dalam pemahaman diri dan perwujudan diri, dalam mencapai tingkat perkembangan, secara optimal dan penyelesaian diri dengan lingkunganya (Surya, 1988). 
Rochman Nata Widjaja mendefiniskan bimbingan sebagai suatu proses pemeberian bantuan kepada individu yang dilakukan secara berkesinambungan supaya individu tersebut dapat memahami dirinya, sehingga individu sanggup mengarahkan dirinya dan dapat bertindak secara wajar, sesuai dengan tuntutan dan keadaan lingkungannya agar mendapatkan kebahagiaan hidup dan memberikan sumbangan berarti kepada masyarakat (Natawidjaja, 1987). Memperhatikan beberapa definisi dan pendapat di atas, dapat disimpulkan bahwa yang dimaksud dengan bimbingan adalah "sesuatu yang dilakukan untuk membantu seseorang dalam kehidupan, membantu memaksimalkan potensi, membuat keputusan dan pemecahan masalah sehingga kehidupan klien bermanfaat bagi dirinya dan orang lain."

Sementara itu, konseling secara terminologi berarti "memberikan arahan dan petunjuk bagi orang yang tersesat, baik arahan tersebut berupa pemikiran, dan orientasi kejiwaan, maupun etika dan penerapannya yang sesuai dan sejalan dengan jalan yang baik atau yang lebih baik darinya dan jauh dari semua bahaya" (Said \& Az-Zahrani, 2005). Dalam kamus istilah konseling dan terapi yang ditulis oleh Andi Mappiere AT, menyebutkan konseling adalah suatu hubungan professional yang mempunyai akar historis pada pendidikan dan bimbingan dan lebih awal adanya serta lebih luas bidang garapannya, misalnya konseling psikologis sebagai salah satu paradigma konseling, juga lebih luas daripada sekedar psikoterapi sebagai salah satu bentuk konseling. Seseorang atau lebih konselor membantu satu atau lebih pribadi klien, untuk berkembang memecahkan masalah, dan mendapatkan pemehaman lebih baik tentang kesulitan, kerisauan, keprihatinan serta perubahan pemikiran, sikap dan tingkah lakudalam bidang-bidang luas diantaranya karir, pekerjaan, sosial, budaya, agama, fisik dan psikis (A.T, 2006). Kegiatan bimbingan dan konseling merupakan jenis keterampilan yang pada intinya mengajak, membimbing, dan mengarahkan klien kembali kepada fitrah, maka siapa saja yang akan mendaami profesi ini, dia harus memiliki keimanan, kemakrifatan, dan ketauhidan yang berkualitas. Karena sudah sangat jelas, bahwa profesi konseling adalah usaha sadar untuk memahami kondisi klien baik secara jasmani maupun secara rohani yang kemudian mengantarkan konseli untuk menemukan solusi.

Penjelaskan mengenai Bimbingan spiritual adalah proses pemberian bantuan kepada individu agar memiliki kemampuan untuk mengembangkan fitrahnya sebagai makhluk 
beragama (homo religious), berperilaku sesuai dengan nilai-nilai agama (berakhlak mulia), dan mengatasi masalah-masalah kehidupan melalui pemahaman, keyakinan, dan praktik-praktik ibadah ritual agama yang dianutnya (Rina, 2013). Terkait akan hal tersebut mengenai spiritual itu sendiri didasarkan atas nilai-nilai agama, sebuah kecerdasan yang berpusat pada nilai keagamaan (Tasmara, 2001). Artinya bimbingan spiritual terdapat intervensi Tuhan dalam kehidupan manusia untuk menolongnya agar dapat mengatasi masalah dan melakukan perubahan ke arah yang lebih baik. Tujuan konseling spiritual adalah pengalaman dan pemantapan identitas spiritual atau keyakinan kepada Tuhan.

Manusia sebagai makhluk sosial satu sama lain saling berinteraksi dan berkomunikasi antara individu dengan individu, kelompok dengan kelompok, atau individu dengan kelompok bahkan dengan lingkungan yang lebih besar yaitu menjadi bagian dari masyarakat secara utuh. Berangkat dari pandangan Behavioristik, setiap individu memiliki pola-pola perilaku unik dan sebagian besar dari kita yakin kalau kita sanggup memahami kenapa kita bersikap dengan cara tertentu bahkan kenapa orang lain berperilaku tertentu (Gibson \& Mitchell, 2011). Dimensi spiritualitas dalam aktivitas konseling menjadi cukup signifikan karena konseling merupakan aktivitas yang fokus pada upaya membantu (building relationship) individu/klien dengan segala potensi dan kemampuan diri untuk mencapai perkembangan yang optimal (Solikin, 2015).

Spiritual merupakan sebuah bentuk multidimensi dan dinamis. Emmons mengatakan bahwa sangatlah sederhana untuk menganggap spiritual sebagai tingkah laku yang pasif dan statis yang dimiliki seseorang, atau perilaku yang terikat di dalamnya, seperti ritual (Emmons, 2000). Secara eksplisit, Piedmont memandang spiritual sebagai rangkaian karakteristik motivasional (motivational trait); kekuatan emosional umum yang mendorong, mengarahkan, dan memilih beragam tiungkah laku individu (Piedmont, 2001). Kemudian sebagai usaha individu untuk memahami sebuah makna yang luas akan pemaknaan akan akan pribadi dalam konteks kehidupan setelah mati (eschatological). Hal ini berarti bahwa sebagai manusia, kita sepenuhnya sadar akan kematian (morality). Dengan demikian, kita akan mencoba untuk membangun beberapa pemahaman akan tujuan dan pemaknaan akan hidup yang sedang di 
jalani. Piedmont membagi spiritualitas atas tiga aspek perilaku spiritual yang dikembangkan Piedmont yaitu Spiritual Transcendence Scale (STS) sebagai berikut:

a. Prayer Fulfillment (pengamalan ibadah), yakni sebuah perasaan gembira dan bahagia yang disebabkan oleh keterlibatan diri dengan realitas trasenden.

b. Universality (universalitas) yakni sebuah keyakinan akan kesatuan kehidupan alam semesta (nature of life) dalam kehidupan dengan dirinya.

c. Connectedness (keterkaitan), yakni sebuah keyakinan bahwa seseorang merupakan bagian dari realitas manusia yang lebih besar yang melampauai generasi dan kelompok tertentu.

Sementara itu dimensi spiritual berfungsi sebagai radar yang mengarahkan pada satu titik tentang kenyataan bahwa terdapat unsur-unsur yang beragam pada diri individu yang tak terjangkau untuk ditelusuri dan dijamah serta menyadarkan bahwa aspek kepribadian yang berkaitan terhadap keyakinan dalam dirinya hanya datang dari sang penggenggam itu sendiri. Dimensi ini menjadi pondasi sebagai tatanan bahwa pentingnya aktivitas bimbingan konseling yang berupa pemberian motivasi serta semangat untuk semakin konsisten dengan profesi yang ditekuni dan menimbulkan keinginan kuat untuk membantu individu/klien.

Pasien rehabilitasi Napza adalah seseorang berupaya pulih dari kondisi kejiwaan yang terganggu akibat penyalahgunaan obat terlarang. Sehingga harus mendapatkan layanan rehabilitasi dalam kurun waktu tertentu dan akan kembali ke lingkungannya setelah masa rehabilitasi selesai. Maka, dengan kondisi yang demikian, sangat memungkinkan seseorang pasien rehabilitasi mengalami tekanan batin, keresahan, dan cara berpikir negatif pula. Bahkan semakin lama mereka mengalami kondisi demikian akan sangat potensial timbulnya gangguan-ganguan psikologis, seperti kecemasan dan depresi.

\section{Metode}

\section{Lokasi penelitian}

Adapun Lokasi dalam penelitian ini di Rumah Sakit Jiwa Sambang Lihum. Rumah Sakit Jiwa Sambang Lihum terletak terletak di wilayah Kecamatan Gambut, Kabupaten Banjar dengan luas areal \pm 10 hektar, berdiri di atas lahan gambut dan jauh dari pemukiman 
penduduk. Rumah Sakit ini berada 500 m dari Jl. Gubernur Syarkawi Km 3,9. Jalan Gubernur Syarkawi merupakan jalan lintas Kalimantan Selatan.

Subjek penelitian

Subjek penelitian yang dilakukan di Rumah Sakit Jiwa Sambang Lihum ini berjumlah 5 orang laki-laki. Adapun karakteristik subjek dalam penelitian ini adalah pasien rawat inap yang di rehabilitasi di Rumah Sakit Jiwa Sambang Lihum. Dari kelima subjek penelitian tersebut memiliki latar belakang berbeda-beda, baik dari segi usia, pendidikan, latar belakang keluarga, dan lama masa rehabilitasi. Selengkapnya identitas subjek dapat dipaparkan dalam tabel berikut ini.

Tabel 1

Identitas Subjek

\begin{tabular}{cccccc}
\hline No & $\begin{array}{c}\text { Subjek } \\
\text { (Inisial) }\end{array}$ & $\begin{array}{c}\text { Usia } \\
\text { (Tahun) }\end{array}$ & $\begin{array}{c}\text { Latar } \\
\text { Belakang } \\
\text { Keluarga }\end{array}$ & Pendidikan & $\begin{array}{c}\text { Lama masa } \\
\text { rehabilitasi }\end{array}$ \\
\hline $\mathbf{1}$ & AR & 17 & Anak & SMA & 2 Bulan \\
$\mathbf{2}$ & AA & 20 & Anak & SMA & 2 Bulan \\
$\mathbf{3}$ & HR & 21 & Anak & SMA & 3 Bulan \\
$\mathbf{4}$ & IL & 19 & Anak & SMA & 3 Bulan \\
$\mathbf{5}$ & MT & 23 & Anak & SMA & 2 Bulan \\
\hline
\end{tabular}

Jenis penelitian

Penelitian ini adalah penelitian lapangan (field research), yaitu penelitian yang pengumpulan datanya dilakukan di lapangan untuk mengadakan pengamatan terhadap suatu fenomena dalam suatu keadaan alamiah. Penelitian ini menggunakan pendekatan deskriptif kualitatif, yakni penelitian yang digunakan untuk memahami fenomena mengenai apa yang dialami subjek penelitian, seperti perilaku, tindakan dengan cara deskripsi dalam bentuk kata dan bahasa, dengan cara penggalian data dari lapangan secara mendalam, luas dan menyeluruh. 
Pengumpulan data

Pengumpulan data dalam penelitian ini dilakukan dengan observasi dan wawancara. Dalam penelitian ini penulis menggunakan observasi nonpartisipan. Adapun data observasi yang diperoleh dalam bentuk keadaan subjek, aktivitas sehari-hari subjek, lingkungan tempat tinggal subjek, perilaku subjek dalam berinteraksi dengan lingkungan sekitar, perilaku subjek saat di masa rehabilitasi, respon subjek terhadap keadaan lingkungan sekitar. Wawancara yang digunakan dalam penelitian ini menggunakan wawancara semi terstruktur. Jenis wawancara ini dipilih agar didapatkan data yang lengkap dan bertujuan untuk menggali data sebanyak mungkin dari responden untuk menemukan permasalahan secara lebih terbuka dan subjek bersangkutan di ajak wawancara untuk dimintai pendapatnya. Sehingga hasilnya berupa identitas subjek, kondisi keluarga subjek, hubungan subjek dengan anggota keluarganya, interaksi subjek dengan lingkungan tempat tinggal subjek, interaksi subjek dengan rekan kerjanya, permasalahan yang terjadi di lingkungan sekitar subjek, faktor-faktor yang menyebabkan subjek sampai mendapatkan binaan rehabilitasi, serta pandangan subjek tentang keberadaan dirinya di lingkungan sekitar subjek.

\section{H a s i 1}

\section{Bimbingan Konseling Spiritual Terhadap Pasien Rehabilitasi Napza}

Berdasarkan data yang diperoleh dari penelitian yang dilakukan peneliti selama 5 hari dengan langsung terjun ke lapangan, kemudian setelah melakukan reduksi data, ditemukan proses bimbingan konseling yang berbasis bimbingan spiritual terhadap kepribadian dan pembermaknaan hidup pasien rehabilitasi Napza. Gambaran tersebut dapat dilihat pada tabel 2 sebagai berikut: 
Tabel 2

Gambaran Bimbingan Konseling Spiritual Terhadap Pasien Rehabilitasi Napza di Rumah Sakit Jiwa Sambang Lihum

\begin{tabular}{|c|c|c|c|c|c|c|}
\hline $\begin{array}{l}\mathbf{N} \\
\mathbf{0}\end{array}$ & $\begin{array}{l}\text { Aspek } \\
\text { Spiritual }\end{array}$ & $\begin{array}{l}\text { Subjek } \\
\text { I (AR) }\end{array}$ & II (AA) & III (HR) & IV (IL) & V (MT) \\
\hline 1 & $\begin{array}{l}\text { Prayer } \\
\text { Fulfillment } \\
\text { (Pengamalan } \\
\text { ibadah) }\end{array}$ & $\begin{array}{l}\text { Setiap hari } \\
\text { melaksanak } \\
\text { an ibadah } 5 \\
\text { waktu } \\
\text { (wajib) }\end{array}$ & $\begin{array}{l}\text { Setiap hari } \\
\text { melaksanak } \\
\text { an ibadah } 5 \\
\text { waktu } \\
\text { (wajib) }\end{array}$ & $\begin{array}{l}\text { Setiap hari } \\
\text { melaksanak } \\
\text { an ibadah } 5 \\
\text { waktu } \\
\text { (wajib) }\end{array}$ & $\begin{array}{l}\text { Setiap hari } \\
\text { melaksanak } \\
\text { an ibadah } 5 \\
\text { waktu } \\
\text { (wajib) }\end{array}$ & $\begin{array}{l}\text {-Setiap hari } \\
\text { melaksanak } \\
\text { an ibadah } 5 \\
\text { waktu } \\
\text { (wajib) }\end{array}$ \\
\hline 2 & $\begin{array}{l}\text { Universalitas } \\
\text { (Keyakinan } \\
\text { hidup) }\end{array}$ & $\begin{array}{l}\text { Memiliki } \\
\text { keyakinan } \\
\text { untuk } \\
\text { kembali } \\
\text { pulih }\end{array}$ & $\begin{array}{l}\text { Keyakinan } \\
\text { subjek } \\
\text { sangat kuat } \\
\text { untuk bisa } \\
\text { hidup } \\
\text { mandiri }\end{array}$ & $\begin{array}{l}\text { Memiliki } \\
\text { tujuan } \\
\text { hidup agar } \\
\text { bisa sukses }\end{array}$ & $\begin{array}{l}\text { Berkeingina } \\
\mathrm{n} \quad \text { bisa } \\
\text { pulang dan } \\
\text { tidak } \\
\text { kembali ke } \\
\text { Napza }\end{array}$ & $\begin{array}{l}\text { Memiliki } \\
\text { keinginan } \\
\text { yang kuat } \\
\text { untuk } \\
\text { sembuh }\end{array}$ \\
\hline 3 & $\begin{array}{l}\text { Keterkaitan } \\
\text { (Tanggung } \\
\text { jawab } \\
\text { terhadap } \\
\text { kehidupann } \\
\text { ya) }\end{array}$ & $\begin{array}{l}\text { Merasa } \\
\text { lebih } \\
\text { menghargai } \\
\text { keluarga }\end{array}$ & $\begin{array}{l}\text { Lebih } \\
\text { menghargai } \\
\text { lingkungan } \\
\text { sekitar, } \\
\text { serta orang- } \\
\text { orang yang } \\
\text { menyayangi }\end{array}$ & $\begin{array}{l}\text { Merasa } \\
\text { bersalah } \\
\text { sudah } \\
\text { memakai } \\
\text { obat } \\
\text { terlarang }\end{array}$ & $\begin{array}{l}\text { Mengambil } \\
\text { manfaat } \\
\text { sebaik } \\
\text { mungkin } \\
\text { selama } \\
\text { masa rehab } \\
\text { agar } \\
\text { menjadi } \\
\text { pribadi } \\
\text { yang baik }\end{array}$ & $\begin{array}{l}\text { Menjalani } \\
\text { program } \\
\text { rebahabilita } \\
\text { si dengan } \\
\text { sabar, agar } \\
\text { pulih. }\end{array}$ \\
\hline
\end{tabular}

\section{Pembahasan}

Berdasarkan data yang dipaparkan pada tabel 2, pada aspek spiritual yang pertama yang berkaitan dengan pengamalan ibadah nampak semua subjek menjalankan kewajibannya menjalankan sholat lima waktu. Dalam program rehabilitasi pengamalan ibadah wajib sudah menjadi kewajiban. Kemudiaan semuanya harus disiplin menjalankan ibadah agar menjadi pola kebiasaan yang baik bagi subjek bersangkutan. Pengamalan ibadah yang lainnya adalah tilawah, sholat malam, dan melakukan sesuatu dengan sopan. 
Aspek kedua pada subjek pertama memiliki keyakinan untuk kembali pulih dengan didasari dari niat dan keinginan hati yang kuat untuk sembuh secara penuh. Subjek kedua berkeyakinan bahwa subjek sangat kuat untuk dapat hidup mandiri setelah masa rehababilitasi sudah selesai ingin mencari pekerjaan agar bisa memenuhi kehidupan sebagai individu yang baik, subjek ketiga memiliki tujuan hidup agar dapat sukses karena ingin berkenginan, subjek keempat berkeinginan dapat pulang dan tidak kembali ke Napza ,subjek kelima memiliki keinginan yang kuat untuk sembuh karena sudah lelah menjalani hidup sebagai pengguna obat terlarang dan berkeinginan menjadi individu yang baik.

Aspek ketiga, subjek pertama merasa lebih menghargai keluarga karena merasa bertanggung jawab atas semua kesalahan terlebih kepada orang tua, subjek kedua lebih dapat menghargai lingkungan sekitar baik itu komponen di lingkungan rehabilitasi atau kepada individu lainnya untuk komunikasi interaksi sosialnya, kemudian subjek ketiga merasa bersalah sudah memakai obat terlarang dan tidak ingin menggunakan obat-obatan lagi sebagai bentuk tanggung jawab pada kehidupannya, subjek ke empat sebagai bentuk tanggung jawabnya berusaha dengan semaksimal mungkin mengambil manfaat selama masa rehab agar menjadi pribadi yang baik, dan seubjek kelima dengan sabar menjalani program rebahabilitasi agar pulih sehingga dapat kembali kekehidupan bermasyarakat.

Berdasarkan paparan data tersebut, kelima subjek memenuhi kriteria perilaku spiritual, yaitu semua perilaku dari aspek spiritual memberikan manfaat bagi mereka sendiri yang berkeinginan sembuh dari napza. Perilaku kelima subjek juga memenuhi indikator spiritual, yaitu perilaku yang kesemua subjek lakukan atas dasar kesadaran dan kecerdasan spiritual secara suka rela demi memulihkan diri mereka

Islam sendiri mengajarkan untuk selalu tolong- menolong dalam kebaikan, pada pembinaan terhadap pengguna napza merupakan hal yang penting dalam meningkatkan pemahaman, penghayatan sekaligus penggunaan nilai-nilai Islam dalam segala aspek kehidupan (Bakri \& Barmawi, 2017).

Pelaksanaan rehabilitasi melalui dakwah di Rumah Sakit Jiwa Sambang Lihum, terdapat kegiatan-kegiatan yang diberikan adalah mengikuti kegiatan belajar ilmu keagamaan, mendengarkan siraman rohani (ceramah keagamaan), shalat berjamaah, membaca al Qur'an 
atau surat-surat pendek, dan do'a bersama setiap hari sebagai upaya pengamalan ibadah yang membentuk perilaku spiritual. Adapun tugas-tugas para konselor rehabilitasi yaitu: Mengajarkan ilmu pengatuhuan agama Islam kepada pasien (dapat disebut sebagai konselor religi), membentuk kepribadian muslim yang kuat, menanamkan kembali spirit keimanan dan ketaqwaan dalam jiwa, mendidik pasien untuk beristiqamah dalam menjalankan ibadah, menanamkan nilai keislaman melalui pendekatan individual, mengajarkan atau memberikan amalan-amalan yang dapat menyadarkan pengguna Napza dari kebiasaan buruknya mengkonsumsi obat terlarang.

\section{Kesimpulan}

Berdasarkan data penelitian yang telah diperoleh, dapat ditarik kesimpulan bahwa pasien rehabilitasi Napza juga dapat di bentuk kepribadiannya dengan memberikan bimbingan dan konseling pada aspek spiritualnya yang mencakup aspek Pengamalan ibadah (Prayer Fulfillment) yang dilakukan oleh kelima subjek dilakukan secara besamaan yaitu pengamalan ibadah, Keyakinan hidup (Universalitas) serta tanggung jawab terhadap kehidupannya (Keterkaitan) telah mereka jalani sepenuhnya sebagai pasien rehabilitasi Napza. Hasilnya adanya perubahan sikap dan mental dari pasien yang sebelumnya ketergantungan manjadi pribadi yang dapat mengelola diri nya dan lebih menghargai arti kehidupan.

\section{Saran}

Berdasarkan kesimpulan tersebut, maka saran penulis untuk beberapa pihak baik itu pemerintah, masyarakat, dan juga orang tua diharapkan dapat memberikan perhatian secara lebih terhadap individu yang terindikasi pengguna Napza, segera melaporkan anaknya apabila diketahui telah terindikasi. Sehingga bisa diberikan sosialisasi dan penyuluhan tentang Napza terutama menganai peran penting dari adanya lembaga rehabilitasi untuk para pengguna Napza.

\section{Kepustakaan}

A.T, A. M. (2006). Kamus Istilah Konseling dan Terapi. Jakarta: Raja Grafindo Persada.

Bakri, N., \& Barmawi. (2017). Efektifitas Rehabilitasi Pecandu Narkotika Melalui Terapi Islami. Jurnal Psikoislamedia, 2(1), 86-93. 
Emmons, R. A. (2000). Is spirituality an intelligence? Motivation, cognition, and the psychology of ultimate concern. The International Journal for the psychology of Religion, 10(1), 3-26.

Gibson, R. L., \& Mitchell, M. H. (2011). Bimbingan dan Konseling. Yogyakarta: Pustaka Pelajar.

Kementerian Kesehatan RI. (2007). Kepmenkes RI No. 812/Menkes/SK/VII/2007 tentang Kebijaka Terapi Paliatif. Jakarta: Kementerian Kesehatan RI.

Komarudin. (2010). Impelementasi Dakwah Melalui Layanan BKI Bagi Pasien Rawat Inap Rumah Sakit di Jawa Tengah (Laporan Penelitian DIKTIS). Semarang: DIKTIS.

Lee, C. C. (2014). Multicultural issues in counseling: New approaches to diversity. United States: John Wiley \& Sons.

Natawidjaja, R. (1987). Pendekatan-Pendekatan dalam Penyuluhan Kelompok. Bandung: Diponegoro.

Piedmont, R. L. (2001). Piedmont, R. L. Spiritual Transcendence and the Scientific Study Of Spirituality, Journal of Rehabilitation, 67(1). Journal of Rehabilitation, 67(1).

Prayitno. (2004). Dasar-Dasar Bimbingan dan Konseling. Jakarta: Rineka Cipta.

Rina, M. (2013). Pendekatan Konseling Spiritual Untuk Mengatasi Masalah Bullying (Kekerasan) Siswa di SMAN 1 Depok Sleman Jogjakarta (Skripsi). Universitas Islam Negeri Sunan Kalijaga, Yogyakarta.

Said, M. bin, \& Az-Zahrani. (2005). Konseling Terapi. Jakarta: Gema Insani Press.

Solikin, A. (2015). Bimbingan Spiritual Berbasis Nilai-Nilai Budaya. Jurnal Attahrir, 15(1).

Suratih, K., Suranah, \& Riyanto. (2014). Pengaruh Bimbingan Spiritual Islami Terhadap Kualitas Hidup Pasien Hemodialisis di RSUD Kabupaten Semarang (Vol. 2). Dipresentasikan pada Prosiding Seminar Nasional II PPNI JawaTengah 2014.

Surya, M. (1988). Dasar-Dasar Konseling Pendidikan, Teori, dan Praktek. Yogyakarta: Kota Kembang.

Tasmara, T. (2001). Kecerdasan Ruhaniah (Tracendental Intelegence) Membentuk Kepribadian yang Bertanggung Jawab, Profesional, dan Berakhlak. Jakarta: Gema Insani Press. 